\title{
A Comparison Between The NORCAT Rover Test Results and the ISRU Excavation System Model Predictions Results
}

\author{
Christopher A. Gallo ${ }^{1}$, Juan H. Agui ${ }^{2}$ and Colin M. Creager ${ }^{3}$ \\ NASA Glenn Research Center, Cleveland, Ohio, 44135 \\ and \\ Heather A. Oravec ${ }^{4}$ \\ The University of Akron, Akron, Ohio, 44325
}

\begin{abstract}
An Excavation System Model has been written to simulate the collection and transportation of regolith on the moon. The calculations in this model include an estimation of the forces on the digging tool as a result of excavation into the regolith. Verification testing has been performed and the forces recorded from this testing were compared to the calculated theoretical data. The Northern Centre for Advanced Technology Inc. rovers were tested at the NASA Glenn Research Center Simulated Lunar Operations facility. This testing was in support of the In-Situ Resource Utilization program Innovative Partnership Program. Testing occurred in soils developed at the Glenn Research Center which are a mixture of different types of sands and whose soil properties have been well characterized. This testing is part of an ongoing correlation of actual field test data to the blade forces calculated by the Excavation System Model. The results from this series of tests compared reasonably with the predicted values from the code.
\end{abstract}

\footnotetext{
${ }^{1}$ Systems Aerospace Engineer, Systems Engineering Division, Mail Stop 86-1, NASA Glenn Research Center, 21000 Brookpark Road, Cleveland, OH 44135

${ }^{2}$ Research Aerospace Engineer, Space Processes \& Experiments Division, Mail Stop 77-5, NASA Glenn Research Center, 21000 Brookpark Road, Cleveland, OH 44135

${ }^{3}$ Research Mechanical Engineer, Structures And Materials Division, Mail Stop 23-3, NASA Glenn Research Center, 21000 Brookpark Road, Cleveland, OH 44135

${ }^{4}$ Research Assistant Professor, College of Engineering, The University of Akron, Akron, OH 44325
} 


\section{Nomenclature}

$\begin{array}{ll}\alpha_{\mathrm{b}} & =\text { blunt edge angle } \\ \beta & =\text { rake angle } \\ \gamma & =\text { soil density } \\ \phi & =\text { internal friction angle } \\ \delta & =\text { external friction angle } \\ \mathrm{c} & =\text { cohesion } \\ \mathrm{d} & =\text { vertical cut depth } \\ \mathrm{e}_{\mathrm{b}} & =\text { blunt edge thickness } \\ \mathrm{g} & =\text { gravitational constant } \\ \mathrm{h} & =\text { soil prism height } \\ \mathrm{l} & =\text { blade height from tip } \\ \mathrm{l}_{\mathrm{s}} & =\text { blade side plate length } \\ \mathrm{q} & =\text { surcharge mass } \\ \mathrm{r} & =\text { blade radius } \\ \mathrm{s} & =\text { side plate thickness } \\ \mathrm{w} & =\text { blade width }\end{array}$

\section{Introduction}

$\mathrm{A}$ lunar outpost has been proposed for the low gravity environment on the moon. This outpost will be used as a research facility and also as a staging area to launch spacecraft to further destinations. Since breathing oxygen and fuel are required, which will be too costly to transport from earth, a process to extract oxygen from the lunar soil is being developed.

The In-Situ Resource Utilization (ISRU) program involves the excavation, transportation and processing of regolith on the moon to extract oxygen. The ISRU excavation activity, which is one part of the overall ISRU program at the Glenn Research Center (GRC), involves the continuing development of a code to simulate the excavation and transportation of this regolith. The results from the code require verification against data from actual testing so there is confidence that the predictions are an accurate representation of the activities on the lunar surface.

The ISRU Excavation System Model developed at GRC is used to predict the forces that vehicles and their attached implements encounter during excavation. The vehicle geometry along with the tire characteristics and plow or bucket dimensions are input to the code as well as the soil characteristics as measured before a test. The Excavation Model includes the Balovnev ${ }^{1}$ equations to estimate digging forces on both a plow and a bucket and the Bekker $^{2}$ equations to estimate the traction force on the vehicle wheels while moving.

The Northern Centre for Advanced Technology Inc. (NORCAT) brought two rovers to the NASA Glenn Research Center in Cleveland, Ohio in December of 2010 for a week of testing in the Simulated Lunar Operations (SLOPE) facility. One rover included a plow mounted to the front which can be used to create level landing pads on the lunar surface. The other rover included a bucket which can be used to collect and haul regolith to a processing facility for oxygen extraction. Additional testing was performed on the bucket only in the NASA Excavation and Traction Testing (NExT2) facility. This test program, performed by both NORCAT and NASA GRC, was in support of the ISRU program Innovative Partnership Program (IPP) that has been established between GRC and NORCAT.

\section{NASA Excavation and Traction Testing (NExT2) Facility Test Description}

The purpose of the NExT2 facility is to test conceptual implements for use on lunar excavation vehicles. Testing in the NExT2 facility allows excavation loads to be applied to the implement only thus eliminating the effects of the rover. This results in more accurate and controlled force data for code calibration. The NORCAT bucket was removed from the rover and tested in the NExT2 facility which is a small, welded steel industrial bin. Fig. 1 shows the NORCAT bucket mounted in the NExT2 test facility after a test. The dimensions of the NExT2 facility are $2.9 \mathrm{~m}$ long x $2.3 \mathrm{~m}$ wide $\times 0.7 \mathrm{~m}$ deep. A mechanism is mounted to the bin that allows the implement to be translated horizontally and vertically. This mechanism allows precise control over the velocity and cut depth of the bucket. A 
six axis load cell is mounted behind the bucket to measure excavation forces while the bucket is translating through the soil. Prior to a test, the soil is first raked to return the soil to a natural loose condition and then leveled with a straight edge. This allows for the soil to be of a similar consistency at the start of each test to eliminate unnecessary variables. The NExT2 facility is filled with soil designated as GRC $-3^{3}$ which is a special blend of sands formulated at GRC to mimic the lunar regolith particle size distribution. GRC-3 includes the finer fraction of the average particle size distribution (particles less than 75 micrometers) which is conservative for excavation testing.

Eleven tests were performed in unpacked GRC-3 soil in the NExT2 facility with two tests being repeats of previous tests. One additional test was performed in compacted GRC-3 soil resulting in a 20 percent increase in soil density. Another test was performed in a separate bin filled with JSC-1 A ${ }^{4}$ lunar soil simulant adjacent to the NExT2 facility bin which allowed the same translation mechanism to be used for both. For all 13 tests, the bucket was at a fixed 5 degree rake angle to the soil. Fig. 2 shows a drawing and the dimensions of the tested bucket. Bucket velocities in the test matrix were 2,5 and $10 \mathrm{~cm} / \mathrm{sec}$ at cut depths of 3,5 and $7 \mathrm{~cm}$. These parameters are set based on limitations of the test equipment and comparison to values used in past analysis and testing. Soil characteristics were measured prior to each test with a cone penetrometer and the density, cohesion and friction angle were extracted from this data to be used as input to the Excavation Model. Measuring the soil before each test accounted for the effect of environmental changes between tests. A laser recorded the soil profile in the bucket and in front of the bucket for the duration of each test. This profile data was used to calculate the surcharge mass parameter vs. time for use in the Balovnev bucket force equations. Surcharge mass is the amount of soil in mass per unit bucket area that piles up in the bucket. As the test progresses, the surcharge mass factor increases as more soil is collected. Fig. 3 shows an outline of the soil volume in the bucket used to calculate the surcharge mass at a test time step.

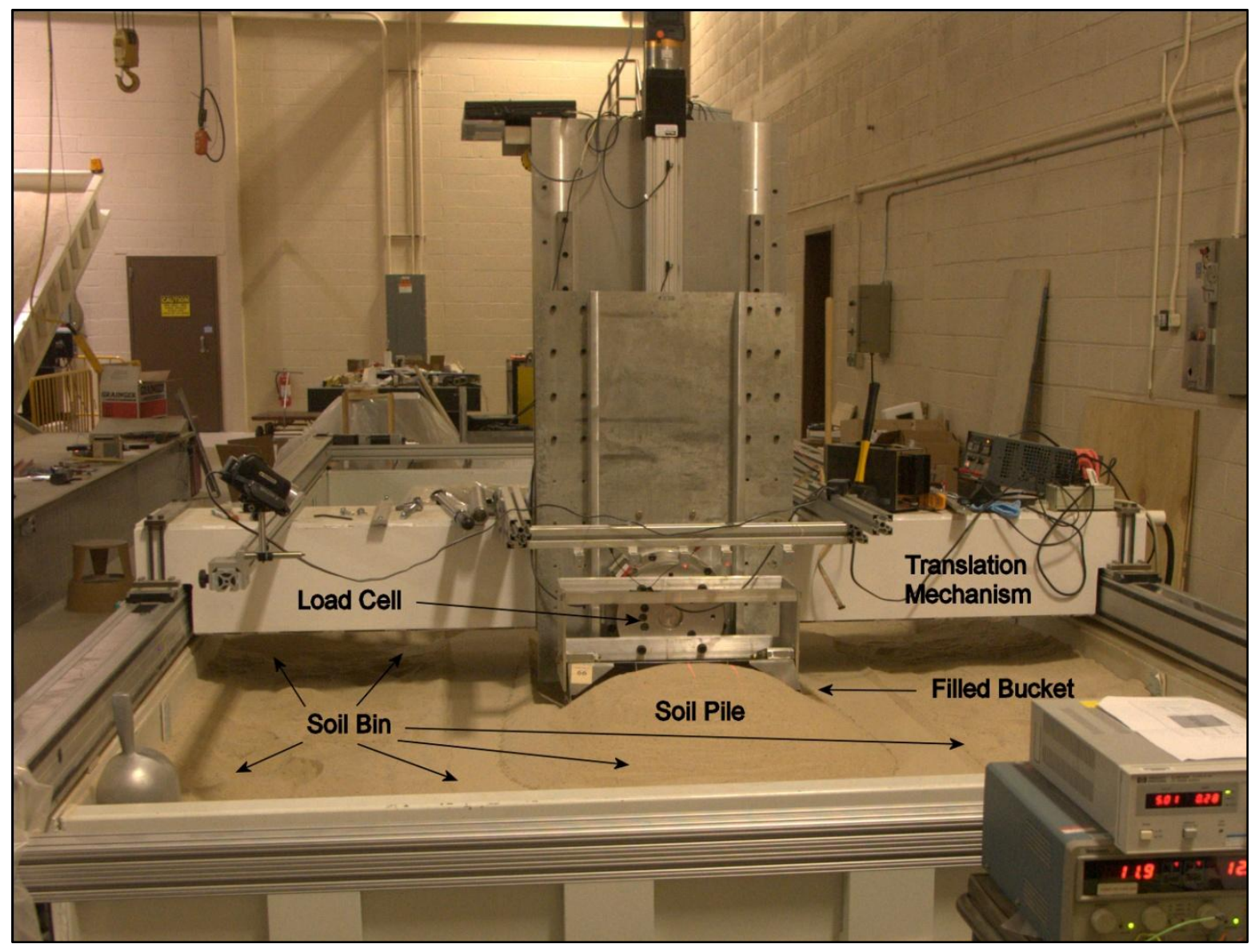

Figure 1. NExT2 Test Facility. 


\section{Bucket Dimensions: \\ Width $=0.51 \mathrm{~m}$ \\ Length $=0.45 \mathrm{~m}$ \\ Height $=0.20 \mathrm{~m}$}

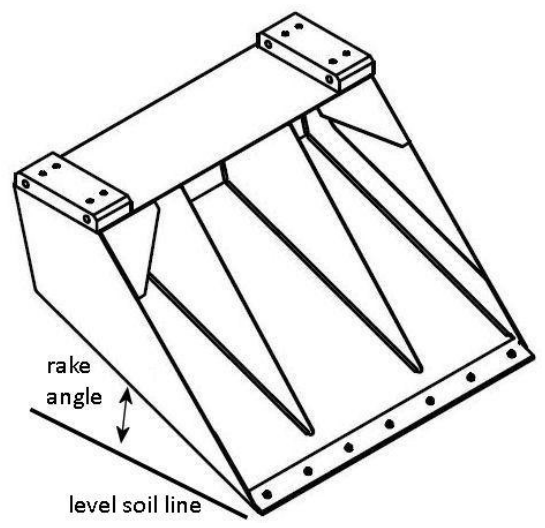

Figure 2. Small Bucket Tested in the NExT2 Facility.

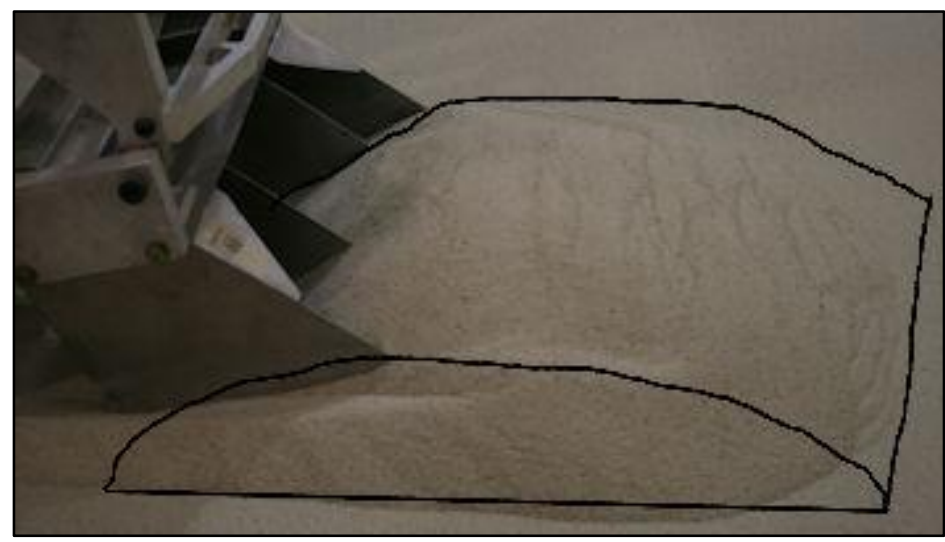

Figure 3. Approximate Soil Volume Outline in Small Bucket for Calculation of Surcharge Mass.

\section{Simulated Lunar Operations (SLOPE) Facility Test Bed Description}

The primary use of the SLOPE facility is to conduct traction and excavation testing of vehicle and component concepts to be used on the lunar surface. The SLOPE facility, as shown in Fig. 4, is filled with GRC-1 ${ }^{5}$ simulated Lunar soil which is a special blend of sands formulated at GRC to mimic the lunar regolith particle size distribution. GRC-1 consists of the coarser fraction of the average particle size distribution (particles greater than 75 micrometers) to create a soil conservative for mobility testing.

The size of the SLOPE facility test bed is $12 \mathrm{~m}$ long x $6 \mathrm{~m}$ wide x $0.3 \mathrm{~m}$ deep and divided into two lanes. The soil is prepared prior to each test by digging over the entire test area with shovels to loosen the soil as well as to erase the soil stress history. The soil is then leveled with a metal plate. The drawbar pull and vehicle excavation tests were performed in this facility.

Two drawbar pull tests were performed at tire pressures of 3 psi (144 Pa) and $6 \mathrm{psi}(287 \mathrm{~Pa})$ to determine the force at which the wheels start to slip. A lower pressure results in improved traction characteristics of the tires. Two pressures were investigated to determine the differences. For these tests, a cable was attached to the back of the plow rover and an increasing force was applied through the cable while the rover was driven forward in the soil with the blade up and not contacting the soil. The cable force was increased causing the wheels to slip. By measuring the drawbar pull (cable) force, the rover velocity and wheel rotational velocity throughout the test, a relationship between wheel slippage and traction force could be determined. The Excavation Model was used to calculate the theoretical drawbar pull at each increment using the rover dimensions and soil parameters. Fig. 5 illustrates the loads the rover will experience during a test.

The excavation tests in the SLOPE facility test bed were performed using two rovers each with different implements mounted to the front of the vehicles. One rover had a 1.7 meter wide plow mounted to the front and the other had a 0.5 meter wide bucket mounted which is the same bucket tested separately in the NExT2 facility described earlier. The plow rover was tested at a tire pressure of $6 \mathrm{psi}(287 \mathrm{~Pa})$ and the bucket rover at a tire pressure of 3 psi (144 Pa). Each rover had load cells mounted behind the implement to measure the forces during excavation. Fig. 6 shows the plow rover and Fig. 7 is a drawing that illustrates the locations of the load cells. Fig. 8 shows the bucket rover and Fig. 9 shows the location of the load cells on this rover. Target velocities were 10, 15 and 20 $\mathrm{cm} / \mathrm{sec}$ and target cut depths were 3,5 and $7 \mathrm{~cm}$. The average measured depth and velocity were used as input for the Excavation Model force predictions. The bucket rover also was tested at rake angles of 5 and 15 degrees to the soil horizontal surface. For each data point, the rover was driven a known distance or until the wheels would encounter high slip (spinning in place) without forward progress. 




Figure 4. Simulated Lunar Operations (SLOPE) Facility.

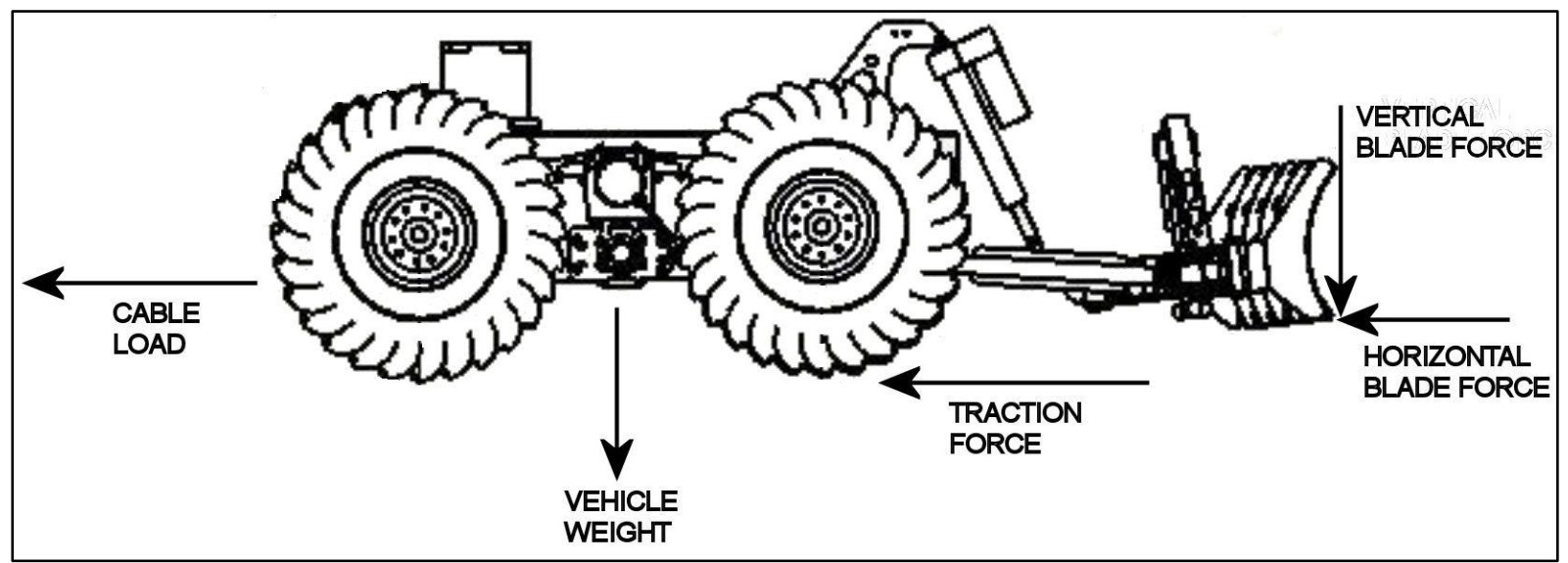

Figure 5. Rover Loads During Testing. 


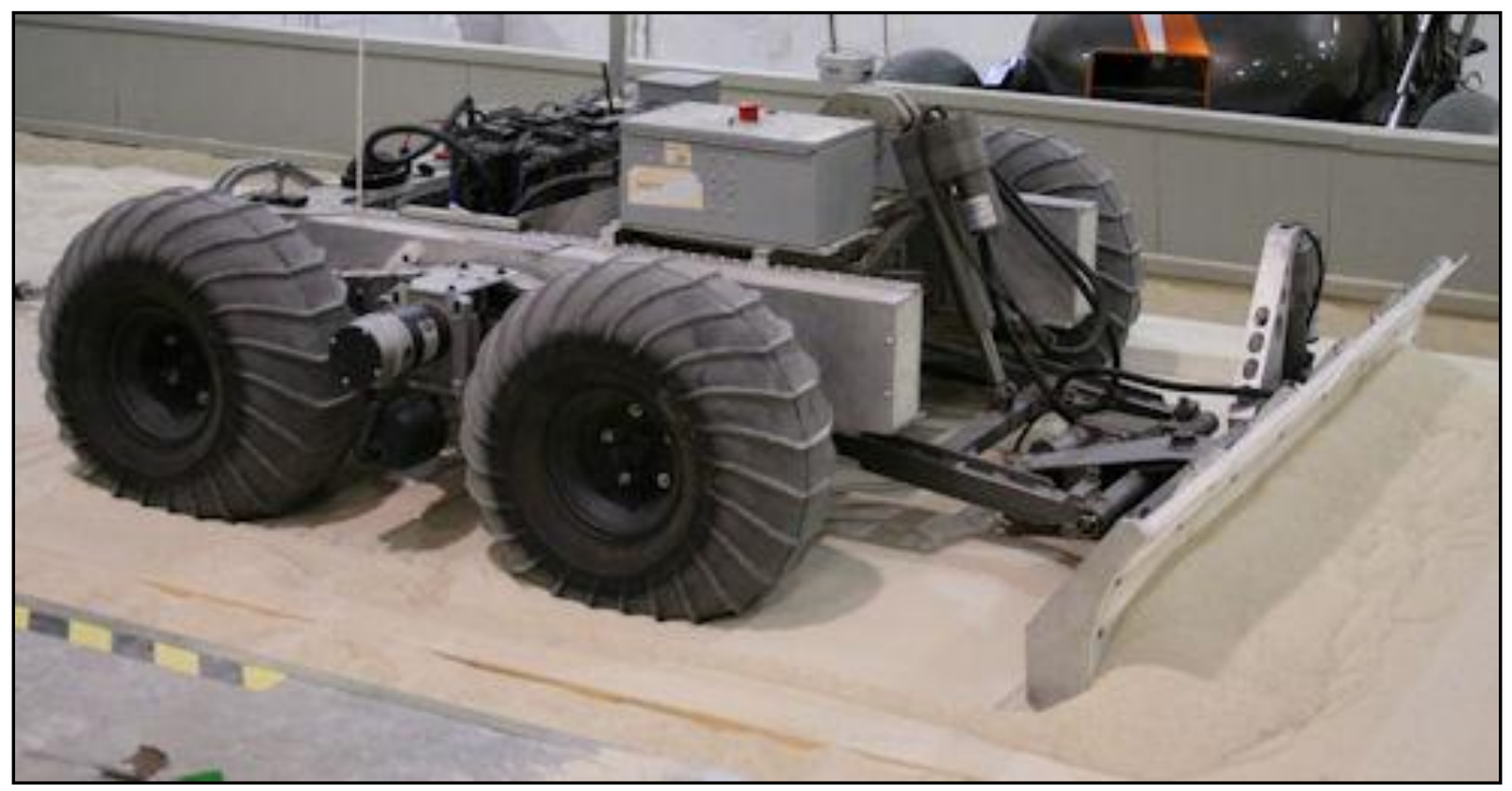

Figure 6. Plow Rover.



Figure 7. Load Cell Location on Plow Rover. 


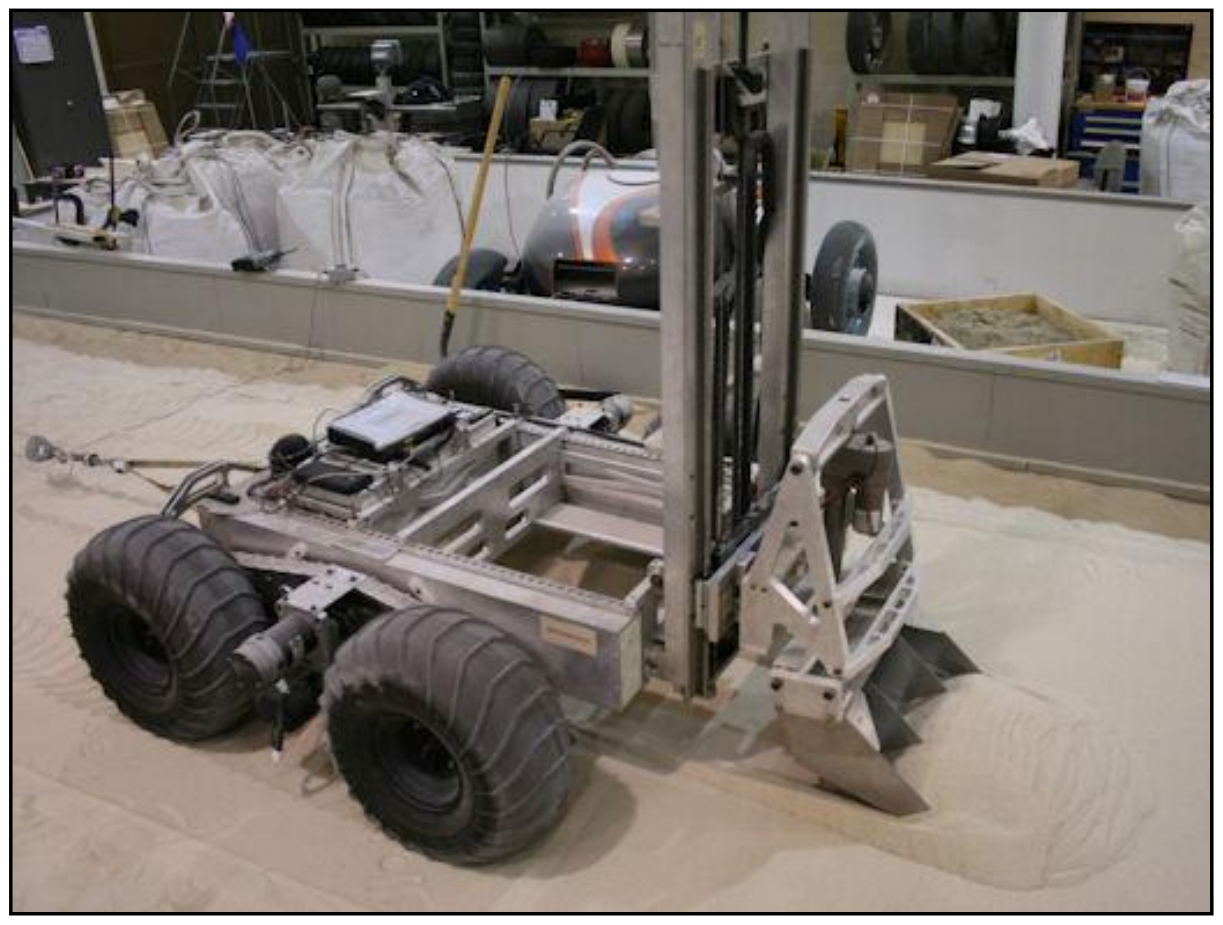

Figure 8. Bucket Rover.

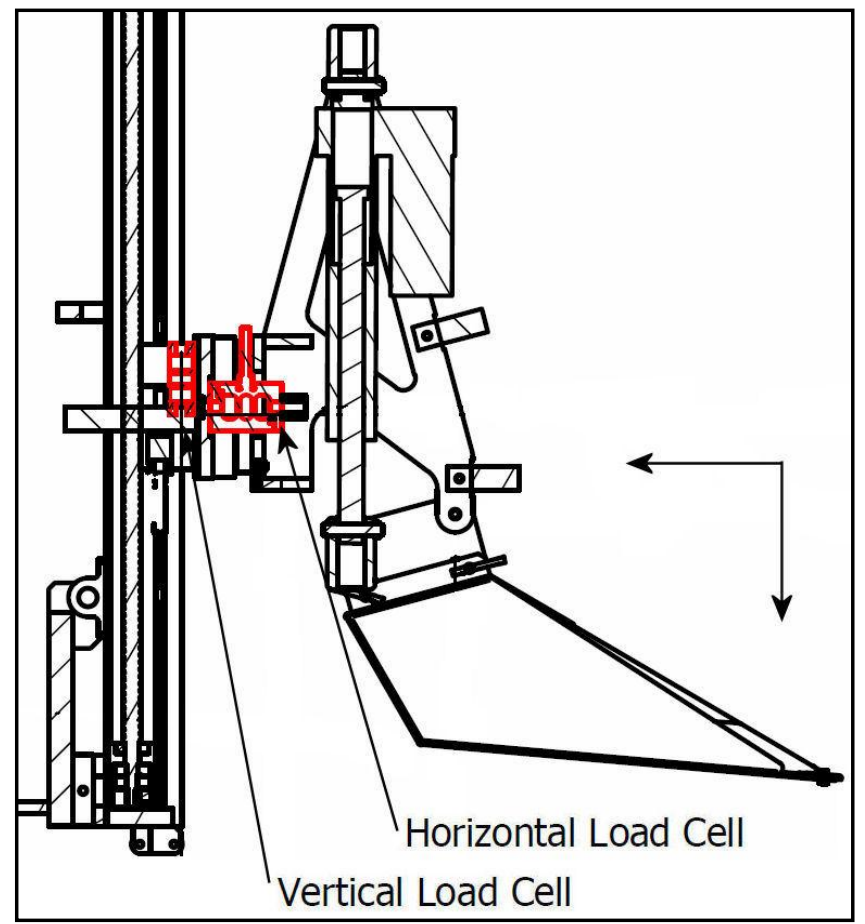

Figure 9. Load Cell Location on Bucket Rover. 


\section{Results}

The geometry of the blade tested in the NExT2 facility along with the GRC-3 soil parameters and cut depth were input into the Excavation Model. The code predicted the forces acting on the blade due to the reaction from the soil using the Balovnev equations ${ }^{6}$ as shown below. Fig. 10 is a diagram of a blade illustrating the variables used in these force equations. After the initial comparison with the test data, it was found that the code predicted blade forces for all tests that were higher than the test data which was due to the effect of the trigonometry function values in the equations at low angles. After some investigation into the Balovnev equations, it was determined that the slope of the calculated force versus rake angle curve increased significantly below rake angles of 10 degrees. A correction was added to the equations so that the code calculated forces followed the same linear slope for rake angles below 10 degrees as for angles above 10 degrees since force should not increase as the bucket becomes more horizontal. The results presented here include this improvement to the equations.

The experimental force results from the bucket tests performed in the NExT2 facility under controlled conditions matched reasonably to the predicted results from the code although the vertical force tends to diverge from the experimental values as the cut depth increases. Table 1 is a list of the measured bucket and soil parameters. A cone penetrometer was used to obtain actual soil measurements prior to each run and the parameters required as input to the code were derived from this data. The resulting average measured load cell force and predicted force on the bucket calculated from the Excavation Model equations are given also.

Figs. 11 through 14 are plots of the code predicted and load cell measured forces for select runs in the NExT2 facility for the duration of each test. The Balovnev equations appear to be overestimating the vertical force on the bucket even after the low rake angle modification to the equations. The difference is greater as the cut depth increases. The Balovnev equations may need to be examined to see if a factor is needed on the cut depth since this trend has been observed with other test validations. Further testing of other buckets at higher rake angles has shown better correlation with the predicted values so the lower rake angle effect in the equations also maybe contributing to the overestimated vertical force values.

$$
\begin{gathered}
H=w d(1+\cot \beta \tan \delta) A_{1}\left(\frac{d g \gamma}{2}+c \cot \phi+g q+B U R I E D *(d-l \sin \beta)\left(g \gamma \frac{1-\sin \phi}{1+\sin \phi}\right)\right)+ \\
w e_{b}\left(1+\tan \delta \cot \alpha_{b}\right) A_{2}\left(\frac{e_{b} g \gamma}{2}+c \cot \phi+g q+d g \gamma\left(\frac{1-\sin \phi}{1+\sin \phi}\right)\right)+ \\
2 s d A_{3}\left(\frac{d g \gamma}{2}+c \cot \phi+g q+B U R I E D *\left(d-l_{s} \sin \beta\right)\left(g \gamma \frac{1-\sin \phi}{1+\sin \phi}\right)\right)+ \\
4 \tan \delta A_{4} l_{s} d\left(\frac{d g \gamma}{2}+c \cot \phi+g q+B U R I E D *\left(d-l_{s} \sin \beta\right)\left(g \gamma \frac{1-\sin \phi}{1+\sin \phi}\right)\right),
\end{gathered}
$$

where BURIED = TRUE or FALSE is a 1 or 0 depending on whether the whole bucket is below the soil surface or not. $A_{1}=A(\beta), A_{2}=A\left(\alpha_{b}\right), A_{3}=A_{4}=A\left(\frac{\pi}{2}\right)$ are geometric factors depending on the angle of a surface with respect to a reference plane. To calculate a particular $A_{i}$ replace $\beta$ with the appropriate argument in the following equation:

$$
\begin{aligned}
& A(\beta)=\quad \frac{1-\sin \phi \cos (2 \beta)}{1-\sin \phi} \quad \text { if } \beta \leq 0.5\left[\sin ^{-1}\left(\frac{\sin \delta}{\sin \phi}\right)-\delta\right] \\
& \frac{\cos \delta\left(\cos \delta+\sqrt{\sin ^{2} \phi-\sin ^{2} \delta}\right)}{1-\sin \phi} e^{\left[2 \beta-\pi+\delta+\sin ^{-1}\left(\frac{\sin \delta}{\sin \phi}\right)\right] \tan \phi} \quad \text { if } \beta>0.5\left[\sin ^{-1}\left(\frac{\sin \delta}{\sin \phi}\right)-\delta\right]
\end{aligned}
$$

The Total and Vertical components of this force are:

$$
\begin{aligned}
& T=H \csc (\beta+\delta) \\
& V=H \cot (\beta+\delta)
\end{aligned}
$$




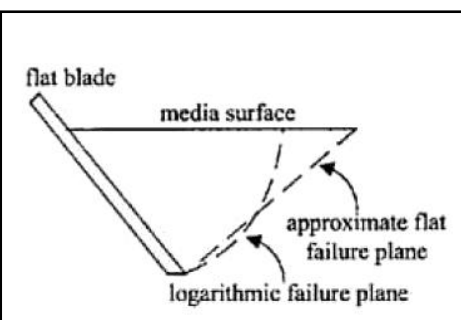

a) Cutting failure planes

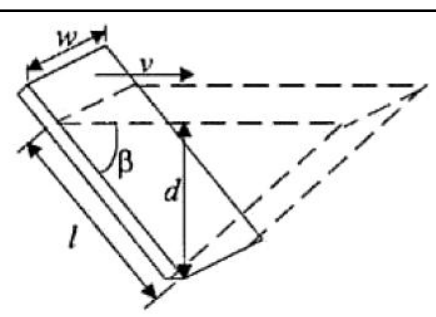

b) Cutting operation variables

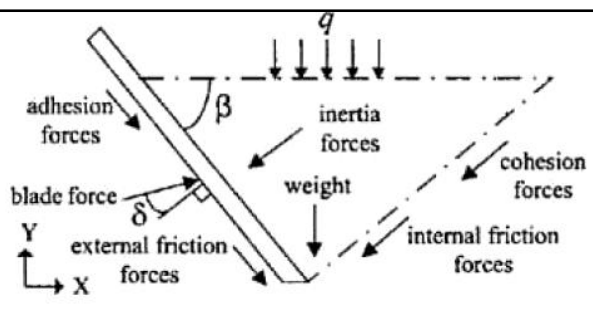

c) Cutting forces

Figure 10. Blade diagram showing variables used in the equations.

\begin{tabular}{|c|c|c|c|c|c|c|c|c|c|c|}
\hline $\begin{array}{l}\text { Test } \\
\text { ID }\end{array}$ & Soil & $\begin{array}{c}\text { Vertical } \\
\text { Cut } \\
\text { Depth }\end{array}$ & $\begin{array}{l}\text { Bucket } \\
\text { Velocity }\end{array}$ & Cohesion & $\begin{array}{l}\text { Internal } \\
\text { Friction } \\
\text { Angle }\end{array}$ & $\begin{array}{l}\text { Regolith } \\
\text { Specific } \\
\text { Mass }\end{array}$ & $\begin{array}{c}\text { Load Cell } \\
\text { Average } \\
\text { Force, N }\end{array}$ & $\begin{array}{l}\text { Balovnev } \\
\text { Average } \\
\text { Force, N }\end{array}$ & $\begin{array}{c}\text { Load Cell } \\
\text { Average } \\
\text { Force, N }\end{array}$ & $\begin{array}{c}\text { Balovnev } \\
\text { Average } \\
\text { Force, N }\end{array}$ \\
\hline & & $\mathrm{cm}$ & $\mathrm{cm} / \mathrm{sec}$ & $\mathrm{N} / \mathrm{m}^{\wedge} 2$ & degree & $\mathrm{kg} / \mathrm{m}^{\wedge} 3$ & \multicolumn{2}{|c|}{ vertical } & \multicolumn{2}{|c|}{ horizontal } \\
\hline 6 & GRC-3 & 3 & 2 & 1 & 30.0 & 1600 & 102 & 157 & 89 & 109 \\
\hline 1 & GRC-3 & 3 & 5 & 1 & 31.0 & 1600 & 108 & 164 & 106 & 118 \\
\hline 12 & GRC-3 & 3 & 5 & 1 & 31.0 & 1560 & 102 & 161 & 100 & 116 \\
\hline 14 & GRC-3* & 3 & 5 & 100 & 32.0 & 1900 & 135 & 255 & 200 & 179 \\
\hline 4 & GRC-3 & 3 & 10 & 1 & 38.0 & 1600 & 112 & 191 & 102 & 121 \\
\hline 11 & GRC-3 & 5 & 2 & 1 & 31.5 & 1550 & 192 & 364 & 177 & 194 \\
\hline 15 & GRC-3 & 5 & 2 & 1 & 30.0 & 1600 & 115 & 272 & 127 & 149 \\
\hline 5 & GRC-3 & 5 & 5 & 1 & 30.0 & 1600 & 207 & 411 & 192 & 211 \\
\hline 7 & GRC-3 & 5 & 10 & 1 & 31.0 & 1550 & 203 & 350 & 192 & 185 \\
\hline 9 & JSC-1A & 7 & 2 & 130 & 30.0 & 1600 & 298 & 876 & 292 & 391 \\
\hline 8 & GRC-3 & 7 & 5 & 300 & 32.0 & 1550 & 297 & 1005 & 291 & 469 \\
\hline 10 & GRC-3 & 7 & 10 & 1 & 31.5 & 1580 & 301 & 777 & 298 & 359 \\
\hline 13 & GRC-3 & 7 & 10 & 10 & 30.0 & 1550 & 305 & 741 & 309 & 377 \\
\hline & * compa & ed soil & & & & & & & & \\
\hline
\end{tabular}

Table 1. Bucket and Soil Parameters and Force Results for NExT2 Facility Test. 


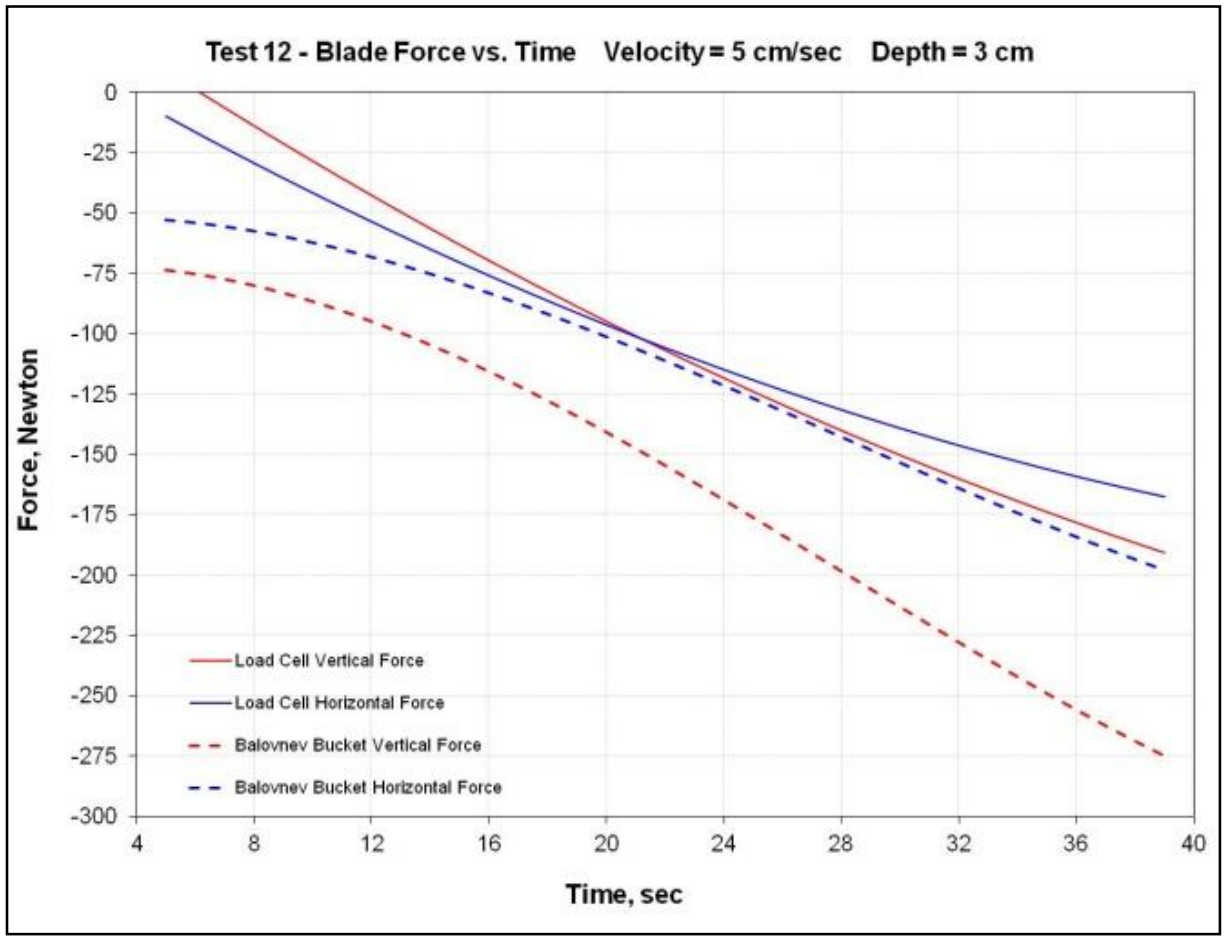

Figure 11. NExT2 Facility Results for Test 12.

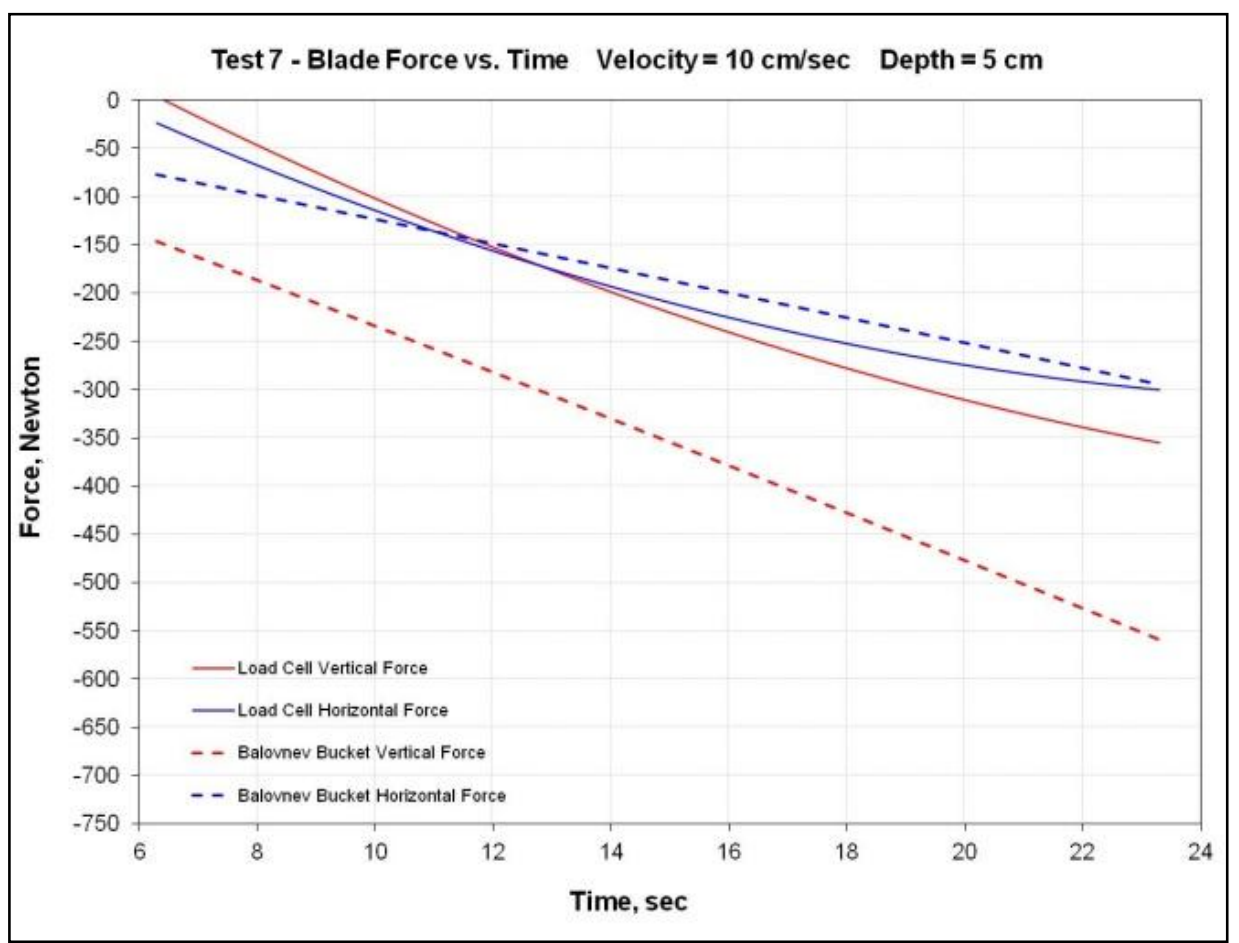

Figure 12. NExT2 Facility Results for Test 7. 


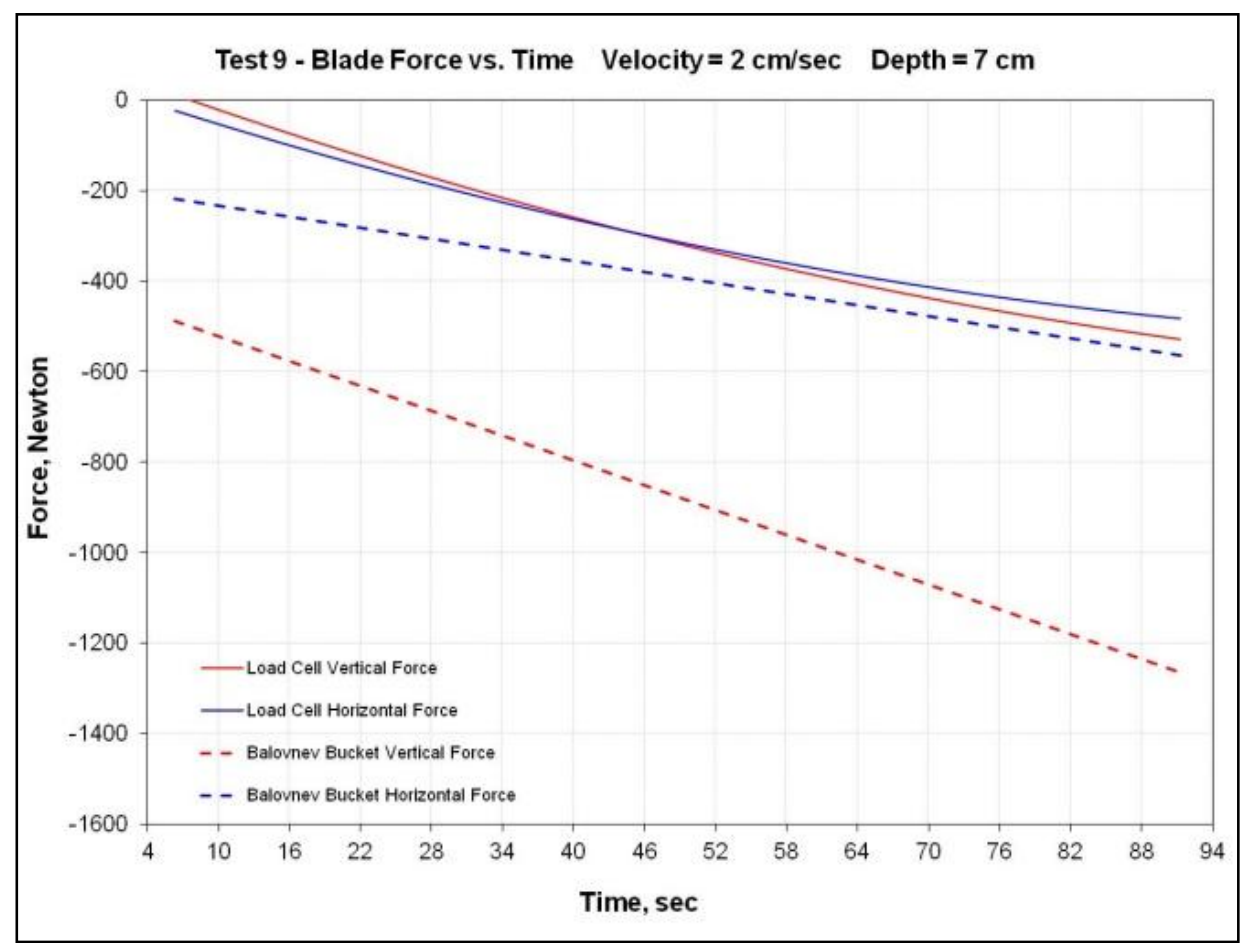

Figure 13. NExT2 Facility Results for Test 9.

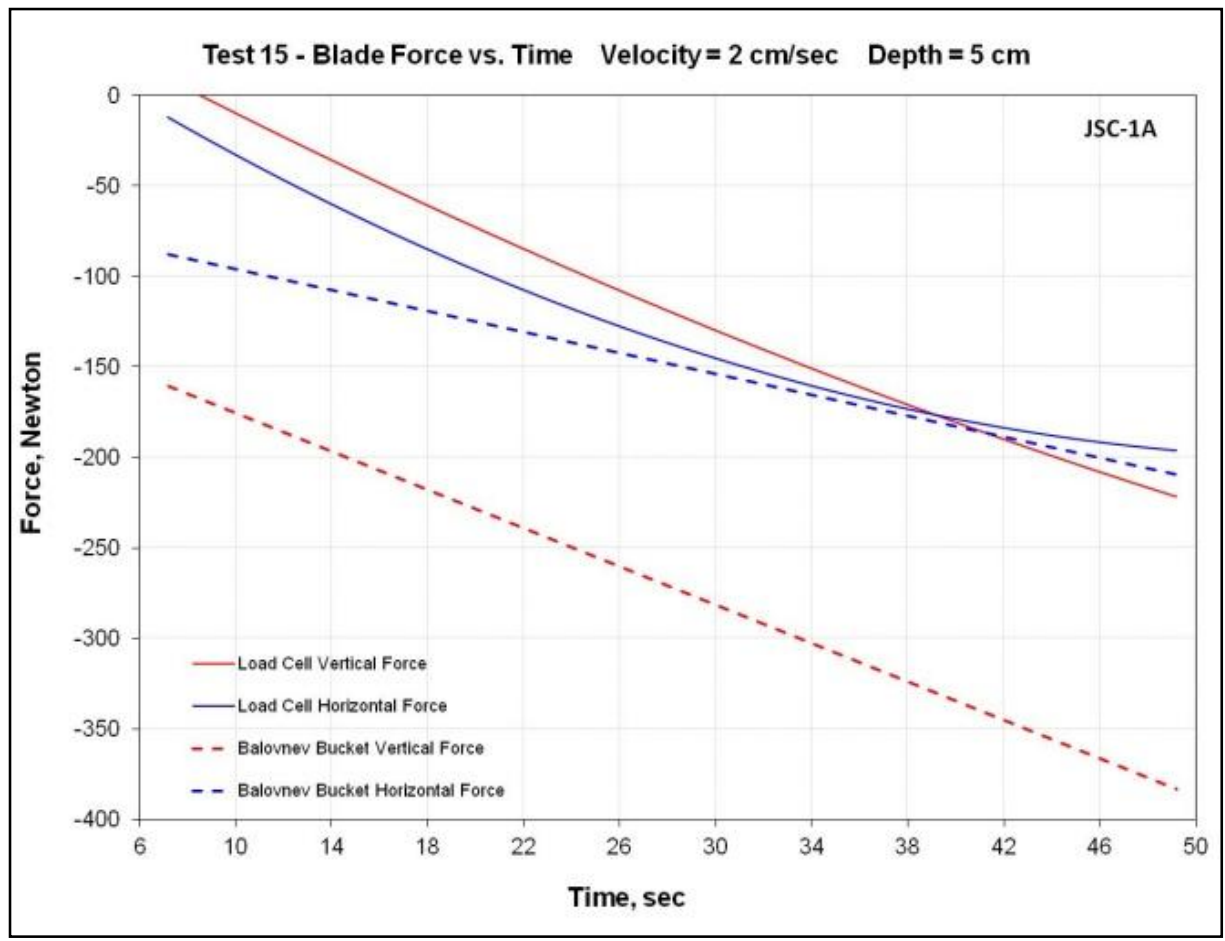

Figure 14. NExT2 Facility Results for Test 15. 
The Bekker traction equations were used in the Excavation Model to obtain theoretical predictions of the drawbar pull force to compare to the experimental data obtained in the SLOPE facility test bed. The forces from the drawbar pull test followed similar trends to those predicted by the code. The experimental drawbar force was lower than the predicted values as wheel slip increased. The Bekker equations require an ideal, uniform vehicle traveling straight and may not account for abnormalities during vehicle travel or the stick-slip of the tires. Calibration of the equations to actual test data may be required. Fig. 15a shows a plot of normalized drawbar pull force versus wheel slip for the rover with 3 psi (144 Pa) tire pressure and Fig. 15b shows the results for 6 psi (287 Pa) tire pressure.
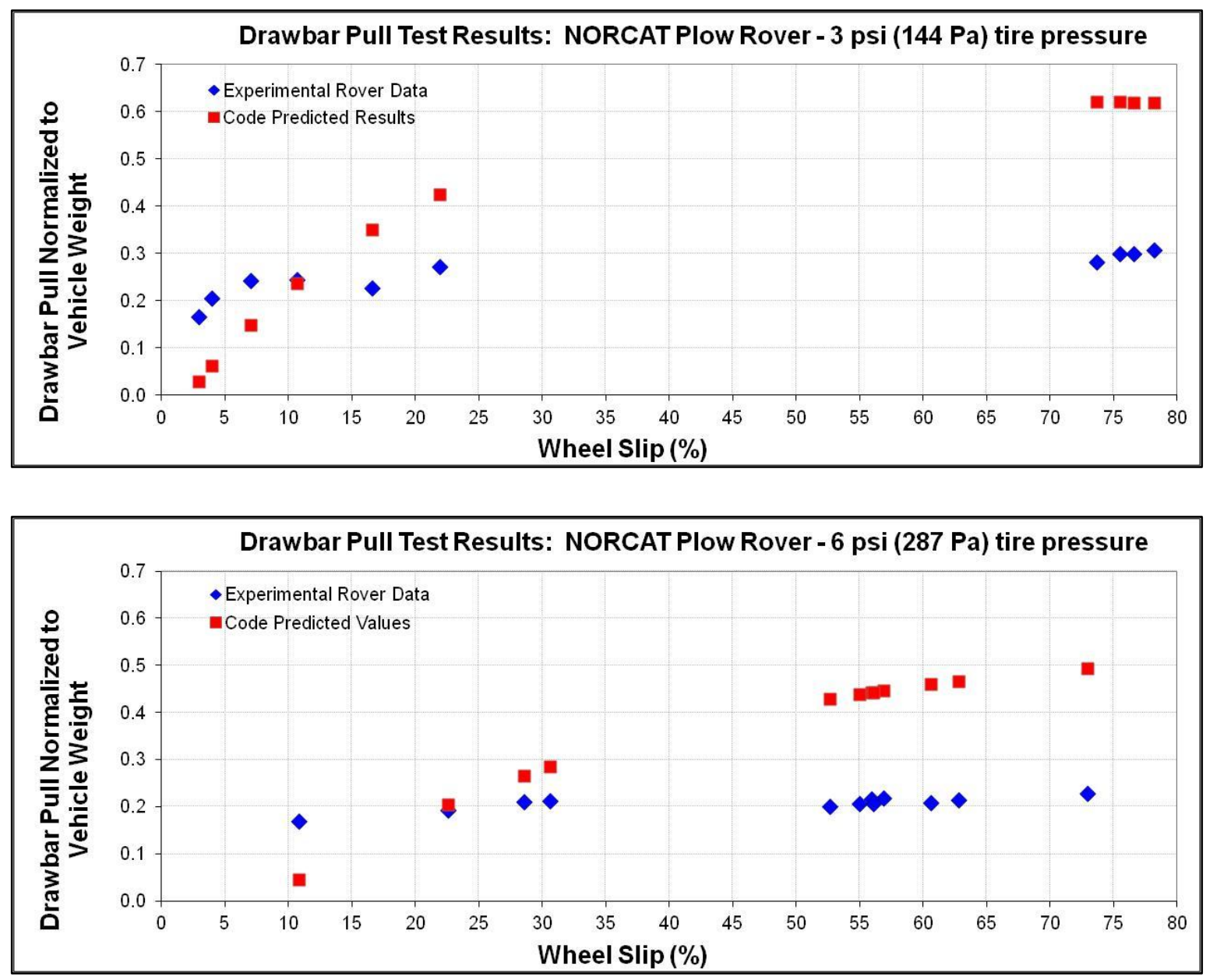

Figures 15a and 15b. Drawbar Pull Test Results.

For the rover excavation testing in the SLOPE facility test bed, the results with the plow mounted to the rover, in general, were near the predicted forces. Table 2 gives the plow parameters and soil properties that were used as input to the Excavation Model. Table 3 presents the average measured cut depth and vehicle velocity and the corresponding experimental and theoretical blade force results for the plow rover test. Fig. 16a. compares the experimental and theoretical vertical forces and Fig. 16b compares the horizontal forces for the plow rover.

The experimental forces from the rover testing with the bucket mounted to the front were lower than the predicted forces for all tests possibly due to load cell calibration issues. Forces should be higher when compared to the experimental data and the results from the plow rover testing. This testing may be repeated in the future with the load cells calibrated. Table 4 gives the bucket parameters and soil properties that were used as input to the Excavation Model. Table 5 summarizes the average measured cut depth and vehicle velocity and the corresponding experimental and theoretical blade force values. From this table, it can be seen that the load cell data is quite lower than the predicted forces. Figs. 17a and 17b present the experimental and theoretical forces for the bucket rover. 


\begin{tabular}{|l|r|l|}
\hline \multicolumn{3}{|c|}{ Plow Parameters } \\
\hline plow width & 1.724 & meter \\
\hline plow length & 0.000 & meter \\
\hline plow height & 0.314 & meter \\
\hline rake angle & 68.0 & degree \\
\hline plow radius & 0.254 & meter \\
\hline blunt edge angle & 68.0 & degree \\
\hline side plate thickness & 0.000 & meter \\
\hline blunt edge thickness & 0.006 & meter \\
\hline \multicolumn{2}{|c|}{ GRC-1 Soil Parameters } & \\
\hline moon gravity & 9.81 & $\mathrm{~m} / \mathrm{sec}^{\wedge} 2$ \\
\hline regolith density & 1625 & $\mathrm{~kg} / \mathrm{m}^{\wedge} 3$ \\
\hline internal friction angle & 31.50 & degree \\
\hline cohesion & 0.00 & $\mathrm{~N} / \mathrm{m}^{\wedge} 2$ \\
\hline external friction angle & 23.63 & degree \\
\hline
\end{tabular}

\begin{tabular}{|c|c|c|c|c|c|}
\hline $\begin{array}{c}\text { Vertical Cut } \\
\text { Depth }\end{array}$ & $\begin{array}{l}\text { Wheel } \\
\text { Velocity }\end{array}$ & $\begin{array}{l}\text { Load Cell } \\
\text { Force, N }\end{array}$ & $\begin{array}{l}\text { Balovnev } \\
\text { Force, N }\end{array}$ & $\begin{array}{l}\text { Load Cell } \\
\text { Force, N }\end{array}$ & $\begin{array}{c}\text { Balovnev } \\
\text { Force, N }\end{array}$ \\
\hline $\mathrm{cm}$ & $\mathrm{cm} / \mathrm{sec}$ & \multicolumn{2}{|c|}{ vertical } & \multicolumn{2}{|c|}{ horizontal } \\
\hline 2.6 & 8.3 & -14 & -2 & 2 & -77 \\
\hline 2.8 & 12.5 & -12 & -2 & 1 & -86 \\
\hline 2.8 & 16.6 & -11 & -2 & 1 & -74 \\
\hline 4.6 & 8.0 & -29 & -5 & -77 & -182 \\
\hline 4.4 & 12.1 & -75 & -6 & 5 & -195 \\
\hline 4.9 & 16.3 & -39 & -7 & -96 & -233 \\
\hline 7.3 & 8.1 & -50 & -12 & 2 & -437 \\
\hline 8.7 & 12.1 & -26 & -16 & -523 & -579 \\
\hline 9.9 & 16.3 & 90 & -20 & -645 & -721 \\
\hline
\end{tabular}

Table 2. Plow and Soil Code Input. Table 3. Experimental and Predicted Forces for Plow Rover.
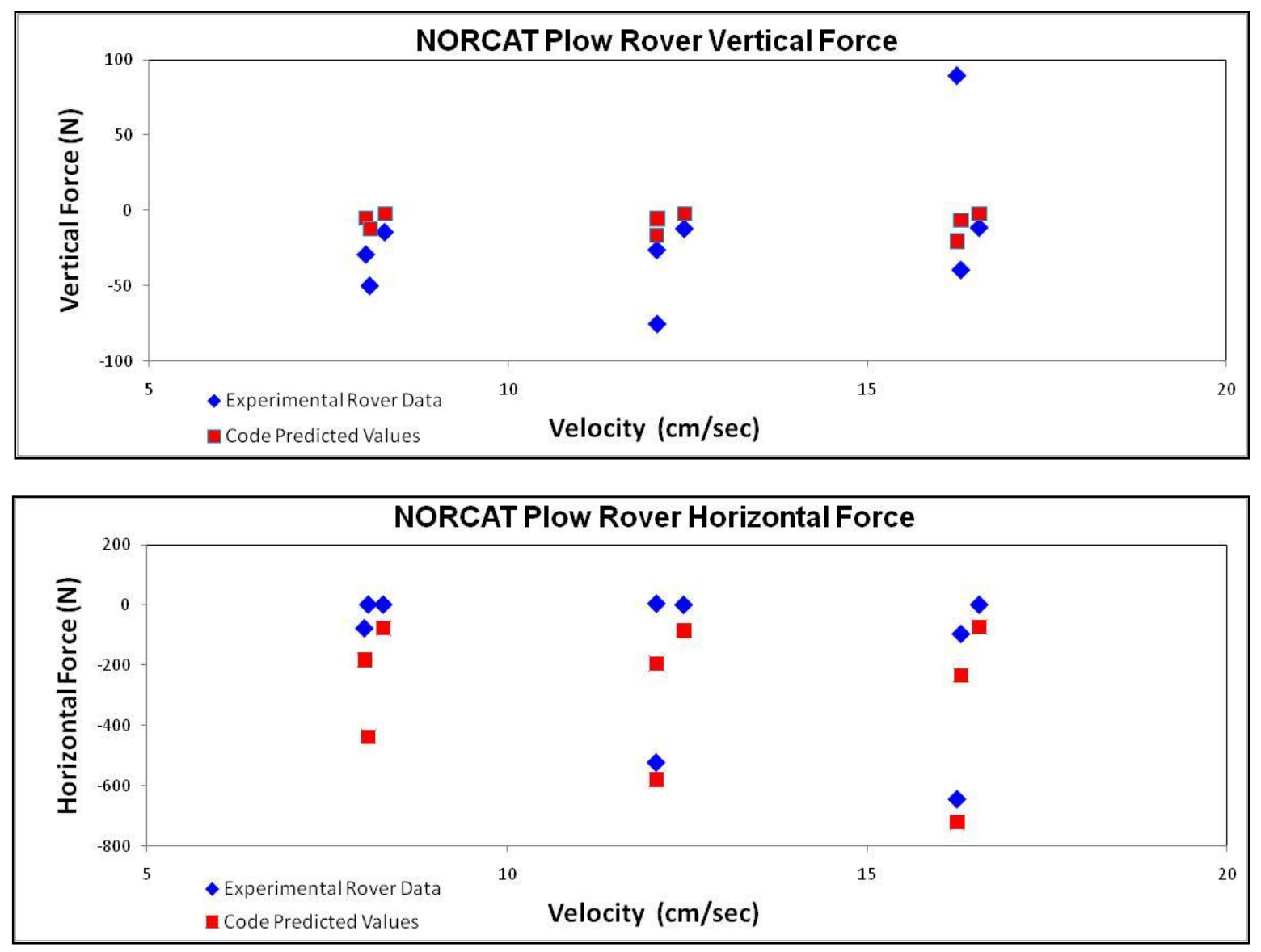

Figures 16a and 16b. Comparison between Experimental and Theoretical Forces for Plow Rover. 


\begin{tabular}{|l|r|l|}
\hline \multicolumn{3}{|c|}{ Bucket Parameters } \\
\hline bucket width & 0.511 & meter \\
\hline bucket length & 0.450 & meter \\
\hline bucket height & 0.200 & meter \\
\hline side plate thickness & 0.003 & meter \\
\hline blunt edge thickness & 0.006 & meter \\
\hline \multicolumn{2}{|c|}{ GRC-1 Soil Parameters } \\
\hline moon gravity & 9.81 & $\mathrm{~m} / \mathrm{sec}^{\wedge} 2$ \\
\hline regolith density & 1625 & $\mathrm{~kg} / \mathrm{m}^{\wedge} 3$ \\
\hline internal friction angle & 31.50 & degree \\
\hline cohesion & 0.00 & $\mathrm{~N} / \mathrm{m}^{\wedge} 2$ \\
\hline external friction angle & 23.63 & degree \\
\hline
\end{tabular}

Table 4. Bucket and Soil Code Input.

\begin{tabular}{|c|c|c|c|c|c|c|}
\hline $\begin{array}{c}\text { Vertical Cut } \\
\text { Depth }\end{array}$ & $\begin{array}{c}\text { Wheel } \\
\text { Velocity }\end{array}$ & $\begin{array}{c}\text { Rake } \\
\text { Angle }\end{array}$ & $\begin{array}{c}\text { Load Cell } \\
\text { Force, N }\end{array}$ & $\begin{array}{c}\text { Balovnev } \\
\text { Force, N }\end{array}$ & $\begin{array}{c}\text { Load Cell } \\
\text { Force, N }\end{array}$ & $\begin{array}{c}\text { Balovnev } \\
\text { Force, N }\end{array}$ \\
\hline $\mathrm{cm}$ & $\mathrm{cm} / \mathrm{sec}$ & degrees & \multicolumn{2}{|c|}{ vertical } & \multicolumn{2}{|c|}{ horizontal } \\
\hline 2.4 & 10.5 & 5 & 17 & 166 & 1.5 & 109 \\
\hline 3.3 & 15.3 & 5 & 14 & 233 & 1.2 & 151 \\
\hline 3.4 & 19.8 & 5 & 27 & 181 & -1.7 & 117 \\
\hline 5.1 & 10.6 & 5 & 16 & 370 & 0.9 & 238 \\
\hline 4.9 & 15.3 & 5 & 16 & 340 & 1.3 & 219 \\
\hline 5.1 & 19.9 & 5 & 26 & 407 & 0.4 & 262 \\
\hline 7.3 & 10.5 & 5 & 16 & 850 & 1.7 & 540 \\
\hline 7.7 & 14.5 & 5 & 12 & 1022 & 1.2 & 649 \\
\hline 9.4 & 19.0 & 5 & 21 & 1458 & 1.2 & 917 \\
\hline 3.1 & 15.2 & 15 & 16 & 90 & 1.2 & 72 \\
\hline 5.2 & 15.0 & 15 & 16 & 301 & 1.3 & 240 \\
\hline 4.7 & 10.5 & 15 & 15 & 208 & 2.5 & 167 \\
\hline 7.6 & 10.5 & 15 & 15 & 561 & 1.5 & 448 \\
\hline
\end{tabular}

Table 5. Experimental and Predicted Forces for Bucket Rover.
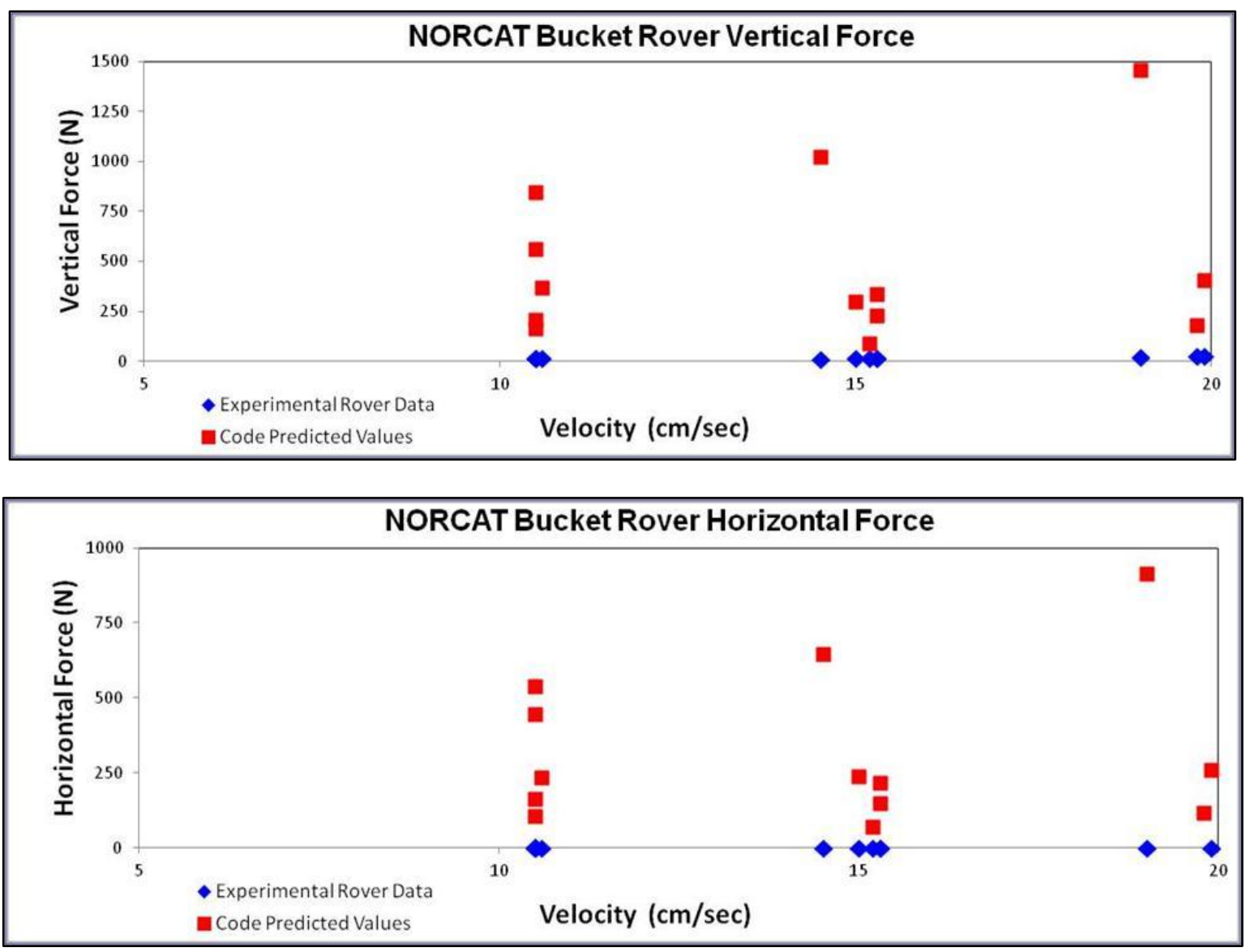

Figures 17a and 17b. Comparison between Experimental and Theoretical Forces for Bucket Rover. 


\section{Conclusion}

The testing performed by the NORCAT rovers in the SLOPE facility and in the NExT2 facility with the NORCAT bucket was successful. Overall, the experimental results compared reasonably to the predicted results from the code. The Excavation System Model coding includes theoretical equations to predict excavation and traction forces which are the basis for the forces presented here. Duplicate tests in the NExT2 facility showed repeatability from the experimental data. The drawbar pull results were close to the theoretical values although the code predicted higher forces as slip increased. The plow rover testing resulted in forces that were near predicted values. Some forces matched well while others were further apart which is probably due to the Balovnev equations over estimating forces at the higher cut depths and lower rake angles. The rover bucket tests resulted in low forces probably due to load cell calibration issues so the theoretical data could not be compared. Based on the usable data, it can be concluded that the methodology in the code reasonably predicts excavation forces obtained from experimental methods.

The rover testing in the SLOPE facility with the bucket may be repeated with load cells that are calibrated and verified to be reading correctly. This will provide additional verification of the model since the data presented here could not be used for verification. Further testing is planned in the NExT2 facility with the bucket at greater rake angles and also with a second bucket that is of similar design to the bucket tested but wider. Both the Balovnev and Bekker equations are predicting forces that are more conservative than the experimental data which has also been observed on other implements and vehicles that have been tested. This allows for a safety factor in case the loads on the moon are higher than those a vehicle is designed to.

\section{References}

${ }^{1}$ Balovnev, V. I., New Methods for Calculating Resistance to Cutting Soil, Amerind Publishing (Translation), P. Data, translator and Rosvuzizdat, New Delhi, Available from National Technical Information Service, Springfield, VA 22161, 1983 and 1963.

${ }^{2}$ Beckker, M. G., Introduction to Terrain-Vehicle Systems, The University of Michigan Press, Ann Arbor, MI, 1969.

${ }^{3} \mathrm{He}, \mathrm{C} .$, Zeng, X. and Wilkinson, A., Geotechnical Properties of GRC-3 Lunar Simulant, Journal of Aerospace Engineering, doi:10.1061/(ASCE)AS.1943-5525.0000162, 2011.

${ }^{4}$ Zeng, X., He, C., Oravec, H., Wilkinson, A., Agui, J., Asnani, V., Geotechnical Properties of JSC-1A Lunar Soil Simulant, Journal of Aerospace Engineering, doi:10.1061/(ASCE)AS.1943-5525.0000014, 2010.

${ }^{5}$ Oravec, H. A., Zeng, X., Asnani, V. M., Design and characterization of GRC-1: A soil for lunar terramechanics testing in Earth-ambient conditions, Journal of Terramechanics, doi:10.1016/j.jterra.2010.04.006, 2010.

${ }^{6}$ Wilkinson, R. A and DeGennaro, A., Digging and Pushing Lunar Regolith: Classical Soil Mechanics and the Forces Needed for Excavation and Traction, Journal of Terramechanics, doi:10.1016/j.jterra.2006.09.001, 2006. 